\title{
Monitoring Dead Space in Mechanically Ventilated Children: Volumetric Capnography Versus Time-Based Capnography
}

\author{
Anoopindar K Bhalla MD, Sarah Rubin MD MSCI, Christopher JL Newth MD, Patrick Ross MD, \\ Rica Morzov RN CPN, Gerardo Soto-Campos PhD, and Robinder Khemani MD MSCI
}

\begin{abstract}
BACKGROUND: Volumetric capnography dead-space measurements (physiologic dead-space-totidal-volume ratio $\left[\mathrm{V}_{\mathrm{D}} / \mathrm{V}_{\mathrm{T}}\right]$ and alveolar $\mathrm{V}_{\mathrm{D}} / \mathrm{V}_{\mathrm{T}}$ ) are considered more accurate than the more readily available time-based capnography dead-space measurement (end-tidal alveolar dead-space fraction [AVDSF]). We sought to investigate the correlation between volumetric capnography and timebased capnography dead-space measurements. METHODS: This was a single-center prospective cohort study of 65 mechanically ventilated children with arterial lines. Physiologic $V_{D} / V_{T}$, alveolar $\mathrm{V}_{\mathrm{D}} / \mathrm{V}_{\mathrm{T}}$, and AVDSF were calculated with each arterial blood gas using capnography data. RESULTS: We analyzed 534 arterial blood gases from 65 children (median age $4.9 \mathrm{y}$, interquartile range 1.7-12.8). The correlation between physiologic $V_{D} / V_{T}$ and AVDSF $(r=0.66,95 \%$ CI 0.59-0.72) was weaker than the correlation between alveolar $V_{\mathrm{D}} / \mathrm{V}_{\mathrm{T}}$ and AVDSF $(\mathrm{r}=\mathbf{0 . 8}, 95 \% \mathrm{CI}$ 0.76-0.85). The correlation between physiologic $\mathrm{V}_{\mathrm{D}} / \mathrm{V}_{\mathrm{T}}$ and AVDSF was weaker in children with low $\mathrm{P}_{\mathrm{aO}} / \mathrm{F}_{\mathrm{IO}_{2}}$ $(<200 \mathrm{~mm} \mathrm{Hg})$, low exhaled $\mathrm{V}_{\mathrm{T}}(<100 \mathrm{~mL})$, a pulmonary reason for mechanical ventilation, or large airway $V_{D}(>3 \mathrm{~mL} / \mathrm{kg})$. All 3 dead-space measurements were highly correlated $(r>0.7)$ in children without hypoxemia $\left(\mathrm{P}_{\mathrm{aO}_{2}} / \mathrm{F}_{\mathrm{IO}_{2}}>300 \mathrm{~mm} \mathrm{Hg}\right)$, mechanically ventilated for a neurologic or cardiac reason, or on significant inotropes or vasopressors. CONCLUSIONS: In mechanically ventilated children without significant hypoxemia or with cardiac output-related dead-space changes, physiologic $V_{D} / V_{T}$ was highly correlated with AVDSF and alveolar $V_{D} / V_{T}$. In children with significant hypoxemia, physiologic $V_{D} / V_{T}$ was poorly correlated with AVDSF. Alveolar $V_{D} / V_{T}$ and AVDSF correlated well in most tested circumstances. Therefore, AVDSF may be useful in most children for alveolar dead-space monitoring. Key words: respiratory dead space; pediatrics; mechanical ventilation; respiratory failure; acute lung injury; capnography. [Respir Care 2015;60(11):1548-1555. () 2015 Daedalus Enterprises]
\end{abstract}

\section{Introduction}

Monitoring dead space in critically ill children is useful for both prognostic and therapeutic reasons. Large dead space in mechanically ventilated children and adults is an

\footnotetext{
The authors are affiliated with the Department of Anesthesiology and Critical Care Medicine, Children's Hospital Los Angeles, Los Angeles, California. Drs Bhalla, Rubin, Newth, Ross, and Khemani are also affiliated with the Keck School of Medicine, University of Southern California, Los Angeles, California.

Dr Bhalla presented a version of this paper at the Society of Critical Care Medicine's 42nd Critical Care Congress, held January 19-23, 2013, in San Juan, Puerto Rico.
}

The authors have disclosed no conflicts of interest. indicator of respiratory disease severity and is associated with increased mortality, longer duration of mechanical ventilation, and higher extubation failure rates. ${ }^{1-8}$ Optimizing mechanical ventilation settings by minimizing dead space has the potential to improve outcomes in children with respiratory failure. ${ }^{9,10}$

Physiologic dead space is composed of both airway dead space and alveolar dead space. In healthy children, the physiologic dead-space-to-tidal-volume ratio $\left(\mathrm{V}_{\mathrm{D}} / \mathrm{V}_{\mathrm{T}}\right)$

\footnotetext{
Correspondence: Anoopindar K Bhalla MD, Children's Hospital Los Angeles, 4650 Sunset Boulevard, MS 12, Los Angeles, CA 90027. E-mail: abhalla@chla.usc.edu.
}

DOI: $10.4187 /$ respcare.03892 
ranges from 0.3 to $0.35 .{ }^{11}$ Airway dead space represents regions of the respiratory system that receive $V_{T}$ but do not normally participate in gas exchange (eg, large conducting airways and the endotracheal tube [ETT] for intubated children). Alveolar dead space (alveoli receiving ventilation without perfusion) is close to zero in healthy children. ${ }^{12}$ However, in critical illness, decreased alveolar perfusion can lead to large alveolar dead space due to alveolar overdistention, decreased cardiac output, or a multitude of other causes. Hence, measuring alveolar dead space provides information on the severity of lung disease and adequacy of pulmonary perfusion, both globally and regionally.

\section{See the Related Editorial on Page 1711}

Volumetric capnography measures the volume of $\mathrm{CO}_{2}$ exhaled with each breath. The mean expiratory $\mathrm{P}_{\mathrm{CO}_{2}}$ and breath-by-breath curve analysis obtained from volumetric capnography, in conjunction with $\mathrm{P}_{\mathrm{aCO}_{2}}$ level, provide the data needed to estimate physiologic, airway, and alveolar $\mathrm{V}_{\mathrm{D}}$. Although it has limitations, volumetric capnography is generally considered an accurate method to evaluate dead space. However volumetric capnography requires specialized equipment not used for most mechanically ventilated children.

On the other hand time-based capnography is routinely used for mechanically ventilated children, reporting the end-tidal $\mathrm{P}_{\mathrm{CO}_{2}}\left(\mathrm{P}_{\mathrm{ETCO}_{2}}\right)$ with each breath. Using the $\mathrm{P}_{\mathrm{ETCO}_{2}}$, the end-tidal alveolar dead-space fraction (AVDSF) can be calculated (AVDSF $\left.=\left[\mathrm{P}_{\mathrm{aCO}_{2}}-\mathrm{P}_{\mathrm{ETCO}_{2}}\right] / \mathrm{P}_{\mathrm{aCO}_{2}}\right)$. Some clinicians use AVDSF at the bedside to monitor changes in dead space. ${ }^{13} \mathrm{P}_{\mathrm{ETCO}_{2}}$ is more representative of alveolar gas than proximal airway gas. ${ }^{14}$ Consequently, AVDSF is viewed as a measurement of alveolar $\mathrm{V}_{\mathrm{D}}$.

The correlation of volumetric capnography dead-space measurements (physiologic and alveolar $\mathrm{V}_{\mathrm{D}} / \mathrm{V}_{\mathrm{T}}$ ) with the time-based capnography dead-space measurement (AVDSF) has not been previously described in mechanically ventilated adults or children. Our primary objective was to determine the correlation strength between physiologic $V_{D} / V_{T}$ and AVDSF. Secondary objectives were to investigate the correlation strength between alveolar $\mathrm{V}_{\mathrm{D}} / \mathrm{V}_{\mathrm{T}}$ and AVDSF and between physiologic and alveolar $\mathrm{V}_{\mathrm{D}} / \mathrm{V}_{\mathrm{T}}$ and to identify factors that may explain the relationships between dead-space measurements.

\section{Methods}

This was a prospective cohort study of mechanically ventilated children $<21$ y of age with arterial lines who were admitted to the pediatric ICU at Children's Hospital Los Angeles between November 2011 and October 2013. Children with an ETT leak of $>20 \%$ ([inhaled - exhaled

\section{QUICK LOOK}

\section{Current knowledge}

Monitoring physiologic dead space in mechanically ventilated children has proven to be useful for both prognostic and therapeutic information. Large dead space in mechanically ventilated children and adults is an indicator of respiratory disease severity and is associated with increased mortality, longer duration of mechanical ventilation, and higher extubation failure rates. Optimizing mechanical ventilation settings by minimizing dead space has been proposed, but has not become routine.

\section{What this paper contributes to our knowledge}

In a group of 65 mechanically ventilated children without significant hypoxemia or cardiac output-related dead-space changes, the dead-space-to-tidal-volume ratio $\left(\mathrm{V}_{\mathrm{D}} / \mathrm{V}_{\mathrm{T}}\right)$ was highly correlated with the end-tidal alveolar dead-space fraction (AVDSF). The correlation between $\mathrm{V}_{\mathrm{D}} / \mathrm{V}_{\mathrm{T}}$ and AVDSF was weaker in children with low $\mathrm{P}_{\mathrm{aO}_{2}} / \mathrm{F}_{\mathrm{IO}_{2}}(<200 \mathrm{mg} \mathrm{Hg}), \mathrm{V}_{\mathrm{T}}<100 \mathrm{~mL}$, a pulmonary reason for mechanical ventilation, or large airway dead space $(>3 \mathrm{~mL} / \mathrm{kg})$. All 3 dead-space measurements were highly correlated $(r>0.7)$ in children without hypoxemia $\left(\mathrm{P}_{\mathrm{aO}_{2}} / \mathrm{F}_{\mathrm{IO}_{2}}>300 \mathrm{~mm} \mathrm{Hg}\right)$, ventilated for a neurologic or cardiac reason, or on significant inotropes or vasopressors. The utility of these measurements to guide clinical decision making remains unclear.

$\mathrm{V}_{\mathrm{T}} \mathrm{J} /$ inhaled $\left.\mathrm{V}_{\mathrm{T}}\right) \times 100$ ), obstructive airway disease (determined by clinical examination or flow-volume loops), on high-frequency oscillatory ventilation, or on CPAP were excluded. ${ }^{15}$ Children on CPAP were excluded due to their generally lower $\mathrm{V}_{\mathrm{T}}$, shorter inspiratory times, and higher breathing frequencies. All children were ventilated with pressure control, pressure-regulated volume control, or pressure support ventilation. The majority of children received continuous sedation during the study period; however, this was not an inclusion criterion. The Children's Hospital Los Angeles institutional review board approved this study with a waiver of informed consent (CCI 11-00243).

An NM3 device (Philips Respironics, Murrysville, Pennsylvania) was used to monitor volumetric capnography according to the recommendations of the manufacturer. NM3 monitoring adds $<1 \mathrm{~mL}$ of airway $\mathrm{V}_{\mathrm{D}}$ for neonatal sensors (ETT size of $2.5-4 \mathrm{~mm}$ ), $<4 \mathrm{~mL}$ of airway $\mathrm{V}_{\mathrm{D}}$ for pediatric sensors (ETT size of $3.5-6 \mathrm{~mm}$ ), and $<8.5 \mathrm{~mL}$ of airway $V_{D}$ for adult sensors (ETT size of $>5.5 \mathrm{~mm}$ ).

At the time of each arterial blood gas test (drawn at the discretion of the treating physicians), volumetric capnography physiologic and alveolar $\mathrm{V}_{\mathrm{D}} / \mathrm{V}_{\mathrm{T}}$ and time-based capnography AVDSF were calculated. The NM3 monitor re- 


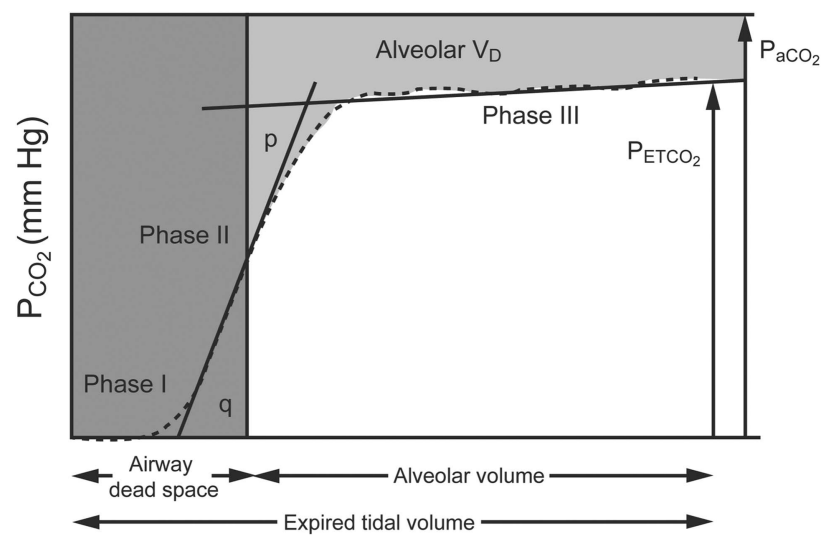

Fig. 1. The intersection of the slope line of phase II and the slope line of phase III is where phase III begins. A perpendicular line divides $p$ and $q$ until they are equal, attributing half of the volume to airway dead space $\left(V_{D}\right)$ and half of the volume to alveolar $V_{D}$. The dark grey area represents airway $V_{D}$. The light grey area represents alveolar $\mathrm{V}_{\mathrm{D}}$. $\mathrm{P}_{\mathrm{ETCO}_{2}}=$ end-tidal $\mathrm{P}_{\mathrm{CO}_{2}}$.

ports $\mathrm{P}_{\mathrm{ETCO}_{2}}$, which was used to calculate AVDSF. Respiratory therapists performed arterial blood gas tests during periods of stability (ie, arterial blood gas tests were not performed within 15 min of ETT suctioning or ventilator changes).

Physiologic $\mathrm{V}_{\mathrm{D}} / \mathrm{V}_{\mathrm{T}}$ was calculated using the Bohr-Enghoff equation: physiologic $\mathrm{V}_{\mathrm{D}} / \mathrm{V}_{\mathrm{T}}=\left(\mathrm{P}_{\mathrm{aCO}_{2}}\right.$ - mean expiratory $\left.\mathrm{P}_{\mathrm{CO}_{2}}\right) / \mathrm{P}_{\mathrm{aCO}_{2}}$. Airway $\mathrm{V}_{\mathrm{D}}$ was estimated by breathto-breath analysis of the volumetric capnography curve by the NM3 monitor (Fowler's method) (Fig. 1). ${ }^{16,17}$ Alveolar $\mathrm{V}_{\mathrm{D}}$ can then be estimated using the calculated physiologic $\mathrm{V}_{\mathrm{D}} / \mathrm{V}_{\mathrm{T}}$ and airway $\mathrm{V}_{\mathrm{D}}$ and the measured exhaled $\mathrm{V}_{\mathrm{T}}(\mathrm{mL})$. Alveolar $\mathrm{V}_{\mathrm{D}}$ = exhaled $\mathrm{V}_{\mathrm{T}}$ (physiologic $\mathrm{V}_{\mathrm{D}} / \mathrm{V}_{\mathrm{T}}$ ) - airway $\mathrm{V}_{\mathrm{D}}$. Alveolar $\mathrm{V}_{\mathrm{D}} / \mathrm{V}_{\mathrm{T}}$ is calculated by dividing alveolar $\mathrm{V}_{\mathrm{D}}$ by alveolar $\mathrm{V}_{\mathrm{T}}$ (obtained from NM3 analysis of the volumetric capnography curve). For each variable, $1 \mathrm{~min}$ of data obtained at the time of the arterial blood gas test was averaged and used for all calculations (an average of 25 breaths/min were analyzed for data calculations). Physiologically impossible values for any measurement were excluded from the analysis (eg, values of AVDSF $<0$ ). This represented $<10 \%$ of the obtained values.

Physiologically plausible confounders of the correlation between dead-space measurements were evaluated, including physiologic $\mathrm{V}_{\mathrm{D}} / \mathrm{V}_{\mathrm{T}}$, exhaled $\mathrm{V}_{\mathrm{T}} / \mathrm{kg}$, exhaled $\mathrm{V}_{\mathrm{T}}$, modified inotrope score, $\mathrm{P}_{\mathrm{aO}_{2}} / \mathrm{F}_{\mathrm{IO}_{2}}$, breathing frequency, reason for mechanical ventilation, PEEP, and airway $\mathrm{V}_{\mathrm{D}}$. A modified inotrope score of the most commonly used vasoactive medications in our pediatric ICU was used: dopamine $(\mu \mathrm{g} / \mathrm{kg} / \mathrm{min})+$ epinephrine $(\mathrm{mg} / \mathrm{kg} / \mathrm{min}) \times 100+$ milrinone $(\mu \mathrm{g} / \mathrm{kg} / \mathrm{min}) \times 10 .{ }^{18}$ The reason for mechanical ventilation was classified as primarily for cardiac, neurologic, or pulmonary reasons. Hypoxemia severity was measured using $\mathrm{P}_{\mathrm{aO}_{2}} / \mathrm{F}_{\mathrm{IO}_{2}}$.

\section{Statistical Analysis}

Analysis was performed using R 2.13 (R Foundation for Statistical Computing, Vienna, Austria) and SAS 9.3 (SAS Institute, Cary, North Carolina). The correlation between (1) physiologic $V_{\mathrm{D}} / \mathrm{V}_{\mathrm{T}}$ and AVDSF, (2) alveolar $\mathrm{V}_{\mathrm{D}} / \mathrm{V}_{\mathrm{T}}$ and AVDSF, and (3) physiologic and alveolar $\mathrm{V}_{\mathrm{D}} / \mathrm{V}_{\mathrm{T}}$ was calculated using the Pearson correlation coefficient with repeated measurements for correlations within subjects. ${ }^{19}$ Correlation coefficients were also calculated within variable subgroups: physiologic $\mathrm{V}_{\mathrm{D}} / \mathrm{V}_{\mathrm{T}}$, exhaled $\mathrm{V}_{\mathrm{T}} / \mathrm{kg}$, exhaled $\mathrm{V}_{\mathrm{T}}$, modified inotrope score, $\mathrm{P}_{\mathrm{aO}_{2}} / \mathrm{F}_{\mathrm{IO}_{2}}$, breathing frequency, reason for mechanical ventilation, PEEP, and airway $\mathrm{V}_{\mathrm{D}}$. There is no statistical test to compare Pearson correlation coefficients with repeated measurements precluding a single $P$ value. For this reason, confidence intervals for each correlation coefficient were calculated using a bootstrap methodology. This simulates the variability of the correlation coefficients by resampling with replacement 1,000 times from the repeated measures of the 2 variables being analyzed and computing the corresponding correlation coefficient each time. ${ }^{20}$ The $95 \%$ CIs were deduced from the histogram of simulated correlation coefficients.

Multivariate mixed linear regression modeling was used to control for patient-level effects while examining potential confounders. The absolute difference between the 2 variables was normally transformed using the log function and used as the dependent variable in the linear regression models. Univariate models were built for (1) $\log$ (absolute [physiologic $\mathrm{V}_{\mathrm{D}} / \mathrm{V}_{\mathrm{T}}-\mathrm{AVDSF}$ ) and (2) $\log$ (absolute [alveolar $\left.\mathrm{V}_{\mathrm{D}} / \mathrm{V}_{\mathrm{T}}-\mathrm{AVDSF}\right]$ ) controlling for patient-level effects first and then examining the effect of each potentially influential variable. Variables with $P<.2$ were considered for inclusion in our multivariate model. Multivariate models controlling for patient-level effects were built, and variables with $P<.05$ remained in the final multivariate model.

\section{Results}

We enrolled 65 mechanically ventilated children (52\% male) with a median age of 4.9 y (interquartile range $1.7-$ 12.8) and median weight of $16.8 \mathrm{~kg}$ (interquartile range 11.2-31.9). The primary reason for mechanical ventilation was pulmonary disease in 26 children (40\%), cardiac disease in 26 children (40\%), and neurologic disease in 13 children (20\%). A mean \pm SD of $8.2 \pm 5.2$ arterial blood gases (range 2-23) per child were evaluated. In total, 534 arterial blood gases were used for the analysis (Table 1). The mean \pm SD difference between the maximum and minimum physiologic $\mathrm{V}_{\mathrm{D}} / \mathrm{V}_{\mathrm{T}}$ per child was $0.14 \pm 0.09$ (median difference 0.14 , minimum difference 0.02 , maximum difference 0.45 , interquartile range $0.07-0.19$ ). 
Table 1. Pulmonary Characteristics at the Time of Arterial Blood Gas Testing

\begin{tabular}{lc}
\hline \hline \multicolumn{1}{c}{ Characteristic } & $\begin{array}{c}\text { All Arterial Blood Gases } \\
(N=534)\end{array}$ \\
\hline AVDSF & $0.16 \pm 0.1$ \\
Alveolar $\mathrm{V}_{\mathrm{D}} / \mathrm{V}_{\mathrm{T}}$ & $0.25 \pm 0.11$ \\
Physiologic $\mathrm{V}_{\mathrm{D}} / \mathrm{V}_{\mathrm{T}}$ & $0.55 \pm 0.12$ \\
$\mathrm{P}_{\mathrm{aO}} / \mathrm{F}_{\mathrm{IO}}, \mathrm{mm} \mathrm{Hg}$ & $234 \pm 118$ \\
Exhaled $\mathrm{V}_{\mathrm{T}} / \mathrm{kg}, \mathrm{mL} / \mathrm{kg}$ & $6.9 \pm 1.9$ \\
Exhaled $\mathrm{V}_{\mathrm{T}}, \mathrm{mL}$ & $114(77-215)$ \\
Modified inotrope score & $2.5(0-15)$ \\
Breathing frequency, breaths/min & $25 \pm 10$ \\
PEEP, cm $\mathrm{H}_{2} \mathrm{O}$ & $8.6 \pm 3.1$ \\
Airway $\mathrm{V}_{\mathrm{D}}, \mathrm{mL} / \mathrm{kg}$ & $2.6 \pm 0.8$ \\
& \\
\hline Normally distributed variables are presented as mean $\pm \mathrm{SD}$. Non-normally distributed \\
variables are presented as median (interquartile range). \\
AVDSF $=$ end-tidal alveolar dead-space fraction \\
$\mathrm{V}_{\mathrm{D}} / \mathrm{V}_{\mathrm{T}}=$ dead-space-to-tidal-volume ratio \\
\hline
\end{tabular}

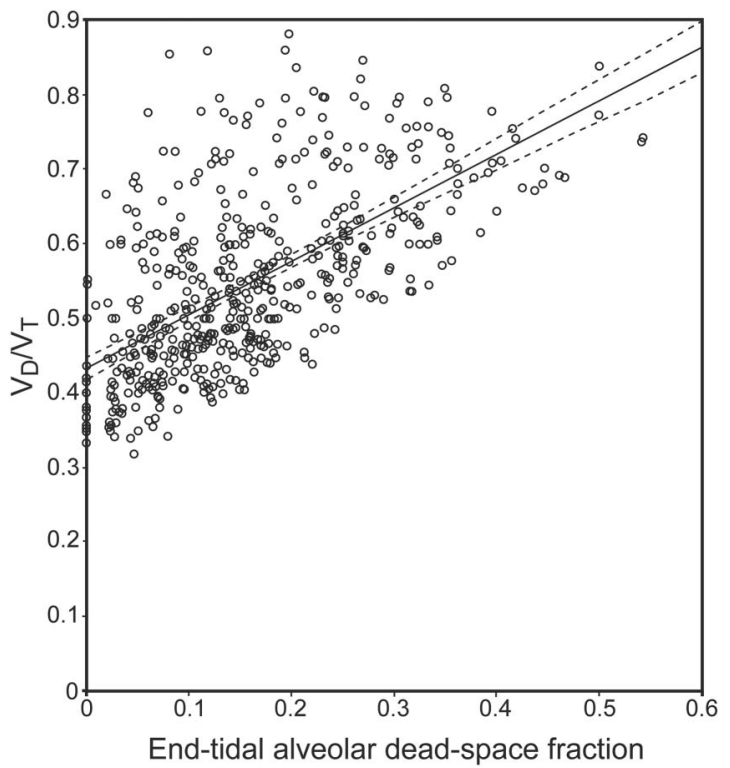

Fig. 2. Scatterplot of physiologic dead-space-to-tidal-volume ratio $\left(\mathrm{V}_{\mathrm{D}} / \mathrm{V}_{\mathrm{T}}\right)$ and end-tidal alveolar dead-space fraction with $95 \% \mathrm{Cl}$ (dashed lines). Within-subjects Pearson correlation coefficient $=0.66(95 \% \mathrm{Cl} 0.59-0.72)$.

\section{Correlation Between Physiologic $\mathrm{V}_{\mathrm{D}} / \mathrm{V}_{\mathrm{T}}$ and AVDSF}

The correlation between physiologic $\mathrm{V}_{\mathrm{D}} / \mathrm{V}_{\mathrm{T}}$ and AVDSF for all arterial blood gases was good $(\mathrm{r}=0.66,95 \%$ CI $0.59-0.72$ ) (Fig. 2 and Table 2). The correlation between physiologic $\mathrm{V}_{\mathrm{D}} / \mathrm{V}_{\mathrm{T}}$ and AVDSF was higher in children with moderately elevated physiologic $\mathrm{V}_{\mathrm{D}} / \mathrm{V}_{\mathrm{T}}(0.4>$ $\mathrm{V}_{\mathrm{D}} / \mathrm{V}_{\mathrm{T}} \leq 0.6$ ), higher $\mathrm{V}_{\mathrm{T}} / \mathrm{kg}$ (exhaled $\mathrm{V}_{\mathrm{T}} / \mathrm{kg}>8 \mathrm{~mL} / \mathrm{kg}$ ), on inotropes or vasopressors, breathing frequencies in the middle range $(20>\mathrm{f}<30$ breaths/min), and low PEEP
( $\leq 6 \mathrm{~cm} \mathrm{H}_{2} \mathrm{O}$ ). On the other hand, in children with significant hypoxemia $\left(\mathrm{P}_{\mathrm{aO}_{2}} / \mathrm{F}_{\mathrm{IO}_{2}}<200\right.$ ), low $\mathrm{V}_{\mathrm{T}}$ (exhaled $\mathrm{V}_{\mathrm{T}}<100 \mathrm{~mL}$ ), mechanically ventilated for pulmonary disease, or large airway $\mathrm{V}_{\mathrm{D}}(>3 \mathrm{~mL} / \mathrm{kg})$, the correlation was lower. Multivariate linear regression analysis demonstrated that the difference between physiologic $\mathrm{V}_{\mathrm{D}} / \mathrm{V}_{\mathrm{T}}$ and AVDSF increased in children with lower $\mathrm{V}_{\mathrm{T}} / \mathrm{kg}(P>.001)$, lower modified inotrope score $(P=.003)$, higher breathing frequency $(P=.009)$, and larger airway $\mathrm{V}_{\mathrm{D}}(P<.001)$ (Table 3).

\section{Correlation Between Alveolar $V_{D} / V_{T}$ and AVDSF}

The correlation between alveolar $\mathrm{V}_{\mathrm{D}} / \mathrm{V}_{\mathrm{T}}$ and AVDSF was strong ( $r=0.80,95 \%$ CI $0.76-0.85)$ (Fig. 3 and see Table 2). The correlation remained strong consistently in all subgroups with the only $\mathrm{r}$ value $<0.65$ in children with a normal-to-low $\mathrm{V}_{\mathrm{D}} / \mathrm{V}_{\mathrm{T}}(\leq 0.4, \mathrm{r}=0.38)$ or small airway $\mathrm{V}_{\mathrm{D}}(\leq 2 \mathrm{~mL} / \mathrm{kg}, \mathrm{r}=0.59)$. In multivariate analysis, lower breathing frequency $(P=.008)$, smaller airway $\mathrm{V}_{\mathrm{D}}$ $(P=.004)$, and higher $\mathrm{V}_{\mathrm{T}} / \mathrm{kg}(P=.03)$ were significantly associated with a larger difference between alveolar $\mathrm{V}_{\mathrm{D}} / \mathrm{V}_{\mathrm{T}}$ and AVDSF (see Table 3). The correlation between alveolar $\mathrm{V}_{\mathrm{D}} / \mathrm{V}_{\mathrm{T}}$ and $\mathrm{AVDSF}$ was statistically significantly higher than the correlation between physiologic $\mathrm{V}_{\mathrm{D}} / \mathrm{V}_{\mathrm{T}}$ and AVDSF when analyzing all arterial blood gases and in many subgroup analyses. In children with a high physiologic $\mathrm{V}_{\mathrm{D}} / \mathrm{V}_{\mathrm{T}}(>0.6)$, significant hypoxemia $\left(\mathrm{P}_{\mathrm{aO}_{2}} / \mathrm{F}_{\mathrm{IO}_{2}}<200\right)$, a large amount of airway $V_{D}(\geq 3 \mathrm{~mL} / \mathrm{kg})$, or on no inotropes or vasopressors (modified inotrope score of 0 ), the correlation between alveolar $V_{D} / V_{T}$ and AVDSF was $r \geq 0.2$ higher than the correlation between physiologic $\mathrm{V}_{\mathrm{D}} / \mathrm{V}_{\mathrm{T}}$ and AVDSF.

The correlation between physiologic and alveolar $\mathrm{V}_{\mathrm{D}} / \mathrm{V}_{\mathrm{T}}$ $(\mathrm{r}=0.66,95 \%$ CI $0.57-0.74)$ was similar to the correlation between physiologic $\mathrm{V}_{\mathrm{D}} / \mathrm{V}_{\mathrm{T}}$ and AVDSF. The correlations between physiologic $\mathrm{V}_{\mathrm{D}} / \mathrm{V}_{\mathrm{T}}$, alveolar $\mathrm{V}_{\mathrm{D}} / \mathrm{V}_{\mathrm{T}}$, and AVDSF were all $\mathrm{r}>0.7$ in children with a high $\mathrm{V}_{\mathrm{T}} / \mathrm{kg}$ $(>8 \mathrm{~mL} / \mathrm{kg})$, minimum hypoxemia $\left(\mathrm{P}_{\mathrm{aO}_{2}} / \mathrm{F}_{\mathrm{IO}_{2}}>300\right)$, low PEEP $\left(<6 \mathrm{~cm} \mathrm{H}_{2} \mathrm{O}\right)$, mechanically ventilated for neurologic or cardiac disease, or on significant inotropes or vasopressors (modified inotrope score of $>10$ ).

\section{Discussion}

Our data demonstrate that AVDSF is highly correlated with both physiologic and alveolar $\mathrm{V}_{\mathrm{D}} / \mathrm{V}_{\mathrm{T}}$ in mechanically ventilated children with changing alveolar $\mathrm{V}_{\mathrm{D}}$ related to cardiac output and in the absence of significant hypoxemia. However, in children with significant hypoxemia, physiologic $V_{D} / V_{T}$ may not adequately indicate changing alveolar $\mathrm{V}_{\mathrm{D}}$, as physiologic $\mathrm{V}_{\mathrm{D}} / \mathrm{V}_{\mathrm{T}}$ is poorly correlated 
Monitoring Dead Space in Mechanically Ventilated Children

Table 2. Correlation Coefficients for All Arterial Blood Gases and Subgroup Analyses

\begin{tabular}{|c|c|c|c|c|}
\hline \multirow{2}{*}{ Subgroup } & \multirow{2}{*}{$n$} & \multicolumn{3}{|c|}{$\mathrm{r}(95 \% \mathrm{CI})$} \\
\hline & & Physiologic $\mathrm{V}_{\mathrm{D}} / \mathrm{V}_{\mathrm{T}}$ and AVDSF & Alveolar $\mathrm{V}_{\mathrm{D}} / \mathrm{V}_{\mathrm{T}}$ and AVDSF & Physiologic and Alveolar $\mathrm{V}_{\mathrm{D}} / \mathrm{V}_{\mathrm{T}}$ \\
\hline All arterial blood gases & 534 & $0.66(0.59-0.72)$ & $0.80(0.76-0.85)$ & $0.66(0.57-0.74)$ \\
\hline \multicolumn{5}{|l|}{ Physiologic $\mathrm{V}_{\mathrm{D}} / \mathrm{V}_{\mathrm{T}}$} \\
\hline$\leq 0.4$ & 47 & $0.42(0.34-0.54)$ & $0.38(0.33-0.56)$ & $0.65(0.58-0.70)$ \\
\hline $0.4-0.6$ & 330 & $0.65(0.61-0.69)$ & $0.73(0.65-0.76)$ & $0.63(0.54-0.67)$ \\
\hline$>0.6$ & 157 & $0.41(0.28-0.45)$ & $0.73(0.69-0.78)$ & $0.41(0.30-0.46)$ \\
\hline \multicolumn{5}{|l|}{ Exhaled $\mathrm{V}_{\mathrm{T}} / \mathrm{kg}$} \\
\hline$\leq 6$ & 185 & $0.66(0.58-0.71)$ & $0.75(0.72-0.82)$ & $0.60(0.56-0.69)$ \\
\hline $6-8$ & 224 & $0.70(0.67-0.75)$ & $0.82(0.79-0.84)$ & $0.82(0.80-0.85)$ \\
\hline$>8$ & 125 & $0.86(0.81-0.86)$ & $0.85(0.83-0.89)$ & $0.82(0.79-0.85)$ \\
\hline \multicolumn{5}{|l|}{ Exhaled $\mathrm{V}_{\mathrm{T}}, \mathrm{mL}$} \\
\hline$<100$ & 223 & $0.54(0.52-0.61)$ & $0.69(0.65-0.72)$ & $0.55(0.47-0.61)$ \\
\hline $100-200$ & 160 & $0.81(0.75-0.84)$ & $0.84(0.78-0.87)$ & $0.78(0.71-0.82)$ \\
\hline$>200$ & 151 & $0.77(0.70-0.80)$ & $0.87(0.83-0.91)$ & $0.77(0.71-0.81)$ \\
\hline \multicolumn{5}{|l|}{ Modified inotrope score } \\
\hline 0 & 256 & $0.48(0.35-0.52)$ & $0.71(0.63-0.73)$ & $0.48(0.34-0.55)$ \\
\hline $0-10$ & 109 & $0.64(0.61-0.76)$ & $0.76(0.75-0.87)$ & $0.61(0.51-0.73)$ \\
\hline$>10$ & 169 & $0.77(0.75-0.83)$ & $0.9(0.89-0.93)$ & $0.82(0.80-0.88)$ \\
\hline \multicolumn{5}{|l|}{$\mathrm{P}_{\mathrm{aO}_{2}} / \mathrm{F}_{\mathrm{IO}_{2}}, \mathrm{~mm} \mathrm{Hg}$} \\
\hline$<200$ & 221 & $0.52(0.40-0.52)$ & $0.80(0.76-0.82)$ & $0.53(0.40-0.53)$ \\
\hline $200-300$ & 153 & $0.70(0.64-0.72)$ & $0.85(0.81-0.87)$ & $0.73(0.68-0.75)$ \\
\hline$\geq 300$ & 160 & $0.73(0.68-0.77)$ & $0.75(0.71-0.80)$ & $0.75(0.68-0.78)$ \\
\hline \multicolumn{5}{|c|}{ Breathing frequency, breaths/min } \\
\hline$\leq 20$ & 181 & $0.63(0.50-0.64)$ & $0.79(0.74-0.82)$ & $0.63(0.55-0.67)$ \\
\hline $20-30$ & 215 & $0.74(0.69-0.77)$ & $0.88(0.85-0.89)$ & $0.79(0.74-0.81)$ \\
\hline$\geq 30$ & 138 & $0.58(0.46-0.59)$ & $0.68(0.61-0.71)$ & $0.46(0.29-0.48)$ \\
\hline \multicolumn{5}{|c|}{ Reason for mechanical ventilation } \\
\hline Cardiac & 241 & $0.75(0.67-0.82)$ & $0.80(0.73-0.86)$ & $0.74(0.66-0.82)$ \\
\hline Neurologic & 105 & $0.73(0.62-0.81)$ & $0.92(0.87-0.95)$ & $0.72(0.62-0.81)$ \\
\hline Pulmonary & 188 & $0.46(0.29-0.60)$ & $0.74(0.65-0.81)$ & $0.48(0.28-0.66)$ \\
\hline \multicolumn{5}{|l|}{ PEEP, $\mathrm{cm} \mathrm{H}_{2} \mathrm{O}$} \\
\hline$\leq 6$ & 142 & $0.74(0.69-0.78)$ & $0.78(0.74-0.83)$ & $0.71(0.65-0.75)$ \\
\hline $6-12$ & 316 & $0.59(0.53-0.66)$ & $0.82(0.79-0.86)$ & $0.64(0.58-0.69)$ \\
\hline$\geq 12$ & 76 & $0.61(0.45-0.66)$ & $0.68(0.56-0.70)$ & $0.47(0.22-0.64)$ \\
\hline \multicolumn{5}{|l|}{ Airway $\mathrm{V}_{\mathrm{D}}, \mathrm{mL} / \mathrm{kg}$} \\
\hline$\leq 2$ & 111 & $0.70(0.65-0.76)$ & $0.59(0.50-0.68)$ & $0.55(0.45-0.66)$ \\
\hline $2-3$ & 270 & $0.69(0.62-0.74)$ & $0.83(0.77-0.85)$ & $0.70(0.56-0.75)$ \\
\hline$\geq 3$ & 153 & $0.54(0.46-0.57)$ & $0.80(0.78-0.84)$ & $0.60(0.53-0.63)$ \\
\hline
\end{tabular}

with both AVDSF and alveolar $\mathrm{V}_{\mathrm{D}} / \mathrm{V}_{\mathrm{T}}$. In most of the conditions tested in this group of children, alveolar $\mathrm{V}_{\mathrm{D}} / \mathrm{V}_{\mathrm{T}}$ and AVDSF correlated well.

All measurements of $V_{D}$ make assumptions and have limitations. Volumetric capnography uses the Enghoff modification of the Bohr equation to estimate the physiologic dead-space fraction by substituting the $\mathrm{P}_{\mathrm{aCO}_{2}}$ for the alveolar $\mathrm{P}_{\mathrm{CO}_{2}}$, assuming they are equal. Alveolar $\mathrm{V}_{\mathrm{D}}$ calculated by volumetric capnography makes this assumption and assumes that the dead-space volume attributable to alve- olar $\mathrm{V}_{\mathrm{D}}$ during phase II of the volumetric capnography curve is equal to airway $\mathrm{V}_{\mathrm{D}}$ (see Fig. 1). Because $\mathrm{P}_{\mathrm{ETCO}_{2}}$ is the maximum $\mathrm{CO}_{2}$ pressure, typically measured at the end of exhalation, AVDSF would be expected to be most representative of alveoli with long emptying times. In contrast, alveolar and physiologic $\mathrm{V}_{\mathrm{D}} / \mathrm{V}_{\mathrm{T}}$ may better account for alveolar emptying heterogeneity represented by the slope of phase III. Furthermore, volumetric and time-based capnography dead-space measurements are affected by a large amount of pulmonary or cardiac shunting, increasing 
Table 3. Multivariate Regression Models

\begin{tabular}{lcc}
\hline \hline \multicolumn{1}{c}{ Model } & $\beta$ & $P$ \\
\hline Model 1: Log(absolute [physiologic & & \\
$\mathrm{V}_{\mathrm{D}} / \mathrm{V}_{\mathrm{T}}-$ AVDSF]) & & \\
Expired $\mathrm{V}_{\mathrm{T}} / \mathrm{kg}$ & -0.030 & $<.001$ \\
Expired $\mathrm{V}_{\mathrm{T}}$ & -0.0001 & .53 \\
Modified inotrope score & -0.001 & .003 \\
Breathing frequency & 0.001 & .009 \\
Airway $\mathrm{V}_{\mathrm{D}}$ & 0.058 & $<.001$ \\
Model 2: Log(absolute [alveolar & & \\
$\mathrm{V}_{\mathrm{D}} / \mathrm{V}_{\mathrm{T}}-$ AVDSF]) & & .03 \\
Expired $\mathrm{V}_{\mathrm{T}} / \mathrm{kg}$ & 0.052 & .69 \\
Expired $\mathrm{V}_{\mathrm{T}}$ & -0.0004 & .008 \\
Breathing frequency & -0.008 & .63 \\
PEEP & -0.004 & .004 \\
Airway $\mathrm{V}_{\mathrm{D}}$ & -0.152 &
\end{tabular}

Multivariate mixed linear regression modeling controlling was used to control for patient-level effects. Variables with a univariate association $(P<.2)$ with the dependent variable were evaluated for the multivariate model. $\beta$ is the regression coefficient.

$\mathrm{V}_{\mathrm{D}} / \mathrm{V}_{\mathrm{T}}=$ dead-space-to-tidal-volume ratio

AVDSF $=$ end-tidal alveolar dead-space fraction

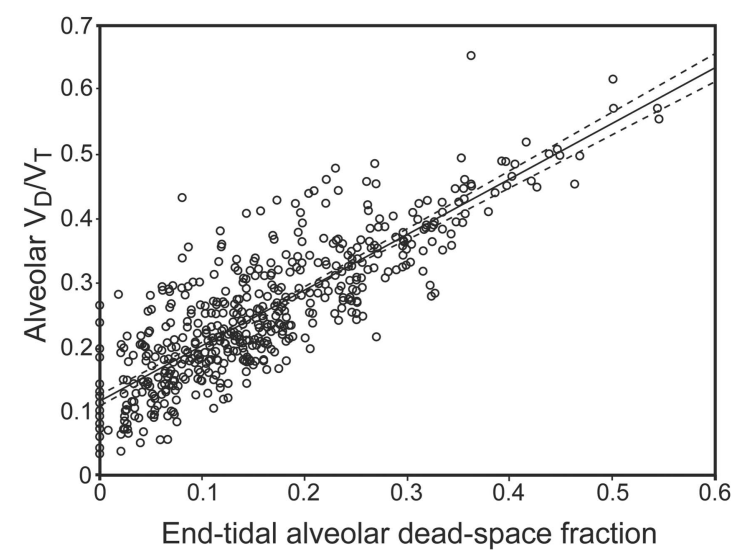

Fig. 3. Scatterplot of volumetric capnography alveolar dead-spaceto-tidal-volume ratio $\left(\mathrm{V}_{\mathrm{D}} / \mathrm{V}_{\mathrm{T}}\right)$ and end-tidal alveolar dead-space fraction with $95 \% \mathrm{Cl}$ (dashed lines). Within-subjects Pearson correlation coefficient $=0.8(95 \% \mathrm{Cl} 0.76-0.85)$.

the $\mathrm{P}_{\mathrm{aCO}}$ more than the alveolar $\mathrm{P}_{\mathrm{CO}_{2}}$ and creating shuntrelated dead space. ${ }^{21}$

Given that physiologic $\mathrm{V}_{\mathrm{D}} / \mathrm{V}_{\mathrm{T}}$, alveolar $\mathrm{V}_{\mathrm{D}} / \mathrm{V}_{\mathrm{T}}$, and AVDSF are each unique dead-space measurements, with none precisely measuring the alveolar or physiologic deadspace fraction, we analyzed how they trended together rather than their ability to estimate each other. Although the correlation between alveolar $\mathrm{V}_{\mathrm{D}} / \mathrm{V}_{\mathrm{T}}$ and AVDSF could be affected by changes in phase III slope, this is unlikely in the subjects in this group, who, for the most part, were not ventilated on high PEEP and had minimum obstructive airway disease. ${ }^{22}$ Although we did not collect data on phase III slopes, we did not find evidence of a weaker correlation between alveolar $\mathrm{V}_{\mathrm{D}} / \mathrm{V}_{\mathrm{T}}$ and AVDSF in children with significant hypoxemia (low $\mathrm{P}_{\mathrm{aO}_{2}} / \mathrm{F}_{\mathrm{IO}_{2}}$ ). Rather, technical limitations in capnography curve interpretation (smaller airway $\mathrm{V}_{\mathrm{D}}$, lower $\mathrm{V}_{\mathrm{D}} / \mathrm{V}_{\mathrm{T}}$ ) appeared to have more impact on the correlation between alveolar $\mathrm{V}_{\mathrm{D}} / \mathrm{V}_{\mathrm{T}}$ and AVDSF. This is logical, as the correlation would be more affected by small variations in capnography curve analysis in these situations. As AVDSF does not represent airway $\mathrm{V}_{\mathrm{D}}$, it should be less correlated with physiologic $\mathrm{V}_{\mathrm{D}} / \mathrm{V}_{\mathrm{T}}$ when changes in airway $V_{D}$ are more prominent than changes in alveolar $\mathrm{V}_{\mathrm{D}}$. This is supported by our multivariate analysis, in which increasing airway $\mathrm{V}_{\mathrm{D}}$ was associated with a larger difference between physiologic $\mathrm{V}_{\mathrm{D}} / \mathrm{V}_{\mathrm{T}}$ and AVDSF. A higher breathing frequency, common in small children, can make it more difficult to interpret both volumetric and time-based capnography curves. ${ }^{23,24}$ This issue was confirmed by our multivariate analysis, demonstrating an association between increasing breathing frequency and a larger difference between physiologic $\mathrm{V}_{\mathrm{D}} / \mathrm{V}_{\mathrm{T}}$ and AVDSF.

The weaker correlation between physiologic $\mathrm{V}_{\mathrm{D}} / \mathrm{V}_{\mathrm{T}}$ and AVDSF may be related to inaccuracies in physiologic $\mathrm{V}_{\mathrm{D}} / \mathrm{V}_{\mathrm{T}}$ or AVDSF calculation or changes in airway $\mathrm{V}_{\mathrm{D}}$ that affect physiologic $\mathrm{V}_{\mathrm{D}} / \mathrm{V}_{\mathrm{T}}$ and not AVDSF. Although not often considered at the bedside, airway $\mathrm{V}_{\mathrm{D}}$ can change in mechanically ventilated children. ${ }^{25,26}$ For example, increasing PEEP in a child with non-recruitable lungs may lead to overdistention of conducting airways. The consistently stronger correlation between alveolar $\mathrm{V}_{\mathrm{D}} / \mathrm{V}_{\mathrm{T}}$ and AVDSF versus physiologic $V_{\mathrm{D}} / \mathrm{V}_{\mathrm{T}}$ and AVDSF suggests that the weaker correlation may frequently be related to changing airway $\mathrm{V}_{\mathrm{D}}$.

Although there are limitations in the accuracy of all these measurements of dead space, both volumetric capnography and time-based capnography dead-space measurements have been consistently associated with worse outcomes in mechanically ventilated children and adults. ${ }^{2-5,27}$ Larger dead space is associated with mortality in children with acute hypoxemic respiratory failure and longer duration of mechanical ventilation in neonates with congenital heart disease.7,28 Increased alveolar $\mathrm{V}_{\mathrm{D}}$ can be due to decreased pulmonary perfusion (microvascular thrombosis, low cardiac output, pulmonary hypertension) or alveolar overdistention. Although it cannot be determined without further study, physiology would suggest that the association between mortality and elevated dead space is due primarily to alveolar $\mathrm{V}_{\mathrm{D}}$, not airway $\mathrm{V}_{\mathrm{D}} \cdot{ }^{29}$ Therefore, future studies should focus on deciphering the source of mortality risk (alveolar or airway $\mathrm{V}_{\mathrm{D}}$ ) and should not report only physiologic dead-space fraction $\left(\mathrm{V}_{\mathrm{D}} / \mathrm{V}_{\mathrm{T}}\right)$.

There is evidence to suggest that dead-space measurement trends, perhaps with the easily monitored AVDSF, should also be investigated further to determine whether they are more useful for prognostication than individual 
values. ${ }^{4}$ Monitoring trends in dead-space measurements can provide continuous bedside information describing improving or deteriorating lung disease and detecting changing pulmonary perfusion. For this reason, capnography is now recommended in cardiopulmonary resuscitation to detect the return of spontaneous circulation by identifying resuming pulmonary perfusion. ${ }^{30}$

Our study has some important limitations. Respiratory therapists actively involved in caring for children rather than research staff recorded the data. This likely resulted in collection of some of the physiologically impossible data. We did not collect breath-to-breath capnogram waveforms with each arterial blood gas test. Evaluation of these may have been helpful to understand how waveform abnormalities affected the correlations. In addition, we did not measure cardiac output, which would have provided data on how pulmonary perfusion directly affected the correlation between AVDSF and physiologic $\mathrm{V}_{\mathrm{D}} / \mathrm{V}_{\mathrm{T}}$. We recognize that $\mathrm{P}_{\mathrm{aO}_{2}} / \mathrm{F}_{\mathrm{IO}_{2}}$ does not fully characterize severity of lung disease; therefore, additional analysis using subgroups based on dynamic compliance was performed, with results consistent with our reported findings (analysis not shown). ETT leaks could affect the correlation between dead-space measurements, and when we performed an analysis limiting data to an ETT leak of $<10 \%$, there was a trend toward improved correlation that did not reach statistical significance. To have a larger sample size for subgroup analysis, we chose to allow an ETT leak of up to $20 \%$.

An advantage of volumetric capnography over timebased capnography is the ability to distinguish between airway and alveolar $\mathrm{V}_{\mathrm{D}}$. This allows a better understanding of how physiologic $\mathrm{V}_{\mathrm{D}} / \mathrm{V}_{\mathrm{T}}$, alveolar $\mathrm{V}_{\mathrm{D}} / \mathrm{V}_{\mathrm{T}}$, and airway $\mathrm{V}_{\mathrm{D}}$ change in response to changing PEEP or $\mathrm{V}_{\mathrm{T}}$ and could be used to optimize ventilator settings based on minimizing dead space. The use of dead-space measurements for therapeutic purposes, in addition to prognostication, may be a promising next step in pediatric mechanical ventilation. A more detailed understanding of airway, alveolar, and physiologic $\mathrm{V}_{\mathrm{D}}$ will help make these therapeutic options a reality.

\section{Conclusions}

For most mechanically ventilated children, AVDSF is analogous to alveolar $\mathrm{V}_{\mathrm{D}} / \mathrm{V}_{\mathrm{T}}$ in estimating changes in alveolar $\mathrm{V}_{\mathrm{D}}$ and is more easily and simply followed at the bedside. As hypoxemia worsens, the correlation between physiologic $\mathrm{V}_{\mathrm{D}} / \mathrm{V}_{\mathrm{T}}$ and AVDSF decreases, perhaps related to changing airway $\mathrm{V}_{\mathrm{D}}$ or limitations in capnography curve analysis. Because alveolar $\mathrm{V}_{\mathrm{D}}$ likely drives the strong relationship between mortality and large dead space, it may be simpler to monitor AVDSF than physiologic $V_{D} / V_{T}$ for prognostic purposes. However, volumetric capnography may be important when using dead-space measurements to guide ventilator support.

\section{REFERENCES}

1. Hubble CL, Gentile MA, Tripp DS, Craig DM, Meliones JN, Cheifetz IM. Deadspace to tidal volume ratio predicts successful extubation in infants and children. Crit Care Med 2000;28(6):2034-2040.

2. Ong T, Stuart-Killion RB, Daniel BM, Presnell LB, Zhuo H, Matthay MA, Liu KD. Higher pulmonary dead space may predict prolonged mechanical ventilation after cardiac surgery. Pediatr Pulmonol 2009;44(5):457-463.

3. Nuckton TJ, Alonso JA, Kallet RH, Daniel BM, Pittet JF, Eisner MD, Matthay MA. Pulmonary dead-space fraction as a risk factor for death in the acute respiratory distress syndrome. N Engl J Med 2002;346(17):1281-1286.

4. Kallet RH, Alonso JA, Pittet JF, Matthay MA. Prognostic value of the pulmonary dead-space fraction during the first 6 days of acute respiratory distress syndrome. Respir Care 2004;49(9):1008-1014.

5. Almeida-Junior AA, da Silva MT, Almeida CC, Ribeiro JD. Relationship between physiologic deadspace/tidal volume ratio and gas exchange in infants with acute bronchiolitis on invasive mechanical ventilation. Pediatr Crit Care Med 2007;8(4):372-377.

6. Arnold JH, Bower LK, Thompson JE. Respiratory deadspace measurements in neonates with congenital diaphragmatic hernia. Crit Care Med 1995;23(2):371-375.

7. Ghuman AK, Newth CJ, Khemani RG. The association between the end tidal alveolar dead space fraction and mortality in pediatric acute hypoxemic respiratory failure. Pediatr Crit Care Med 2012;13(1):1115.

8. Coss-Bu JA, Walding DL, David YB, Jefferson LS. Dead space ventilation in critically ill children with lung injury. Chest 2003; 123(6):2050-2056.

9. Fengmei G, Jin C, Songqiao L, Congshan Y, Yi Y. Dead space fraction changes during PEEP titration following lung recruitment in patients with ARDS. Respir Care 2012;57(10):1578-1585.

10. Yang Y, Huang Y, Tang R, Chen Q, Hui X, Li Y, et al. Optimization of positive end-expiratory pressure by volumetric capnography variables in lavage-induced acute lung injury. Respiration 2014;87(1): $75-83$.

11. Kerr AA. Dead space ventilation in normal children and children with obstructive airways disease. Thorax 1976;31(1):63-69.

12. Sivan Y, Eldadah MK, Cheah TE, Newth CJ. Estimation of arterial carbon dioxide by end-tidal and transcutaneous $\mathrm{P}_{\mathrm{CO}_{2}}$ measurements in ventilated children. Pediatr Pulmonol 1992;12(3):153-157.

13. Rodger MA, Jones G, Rasuli P, Raymond F, Djunaedi H, Bredeson CN, Wells PS. Steady-state end-tidal alveolar dead space fraction and D-dimer: bedside tests to exclude pulmonary embolism. Chest 2001;120(1):115-119.

14. Anderson CT, Breen PH. Carbon dioxide kinetics and capnography during critical care. Crit Care 2000;4(4):207-215.

15. Main E, Castle R, Stocks J, James I, Hatch D. The influence of endotracheal tube leak on the assessment of respiratory function in ventilated children. Intensive Care Med 2001;27(11):1788-1797.

16. Fowler WS. Lung function studies; the respiratory dead space. Am J Physiol 1948;154(3):405-416.

17. Fletcher R, Jonson B, Cumming G, Brew J. The concept of deadspace with special reference to the single breath test for carbon dioxide. Br J Anaesth 1981;53(1):77-88.

18. Rosenzweig EB, Starc TJ, Chen JM, Cullinane S, Timchak DM, Gersony WM, et al. Intravenous arginine-vasopressin in children with vasodilatory shock after cardiac surgery. Circulation 1999; 100(19 Suppl):II182-II186. 


\section{Monitoring Dead Space in Mechanically Ventilated Children}

19. Bland JM, Altman DG. Calculating correlation coefficients with repeated observations: part 1 -correlation within subjects. BMJ 1995; 310(6977):446.

20. DiCiccio TJ, Efron B. Bootstrap confidence intervals. Stat Sci 1996; 11(3):189-228.

21. Tusman G, Suarez-Sipmann F, Paez G, Alvarez J, Bohm SH. States of low pulmonary blood flow can be detected non-invasively at the bedside measuring alveolar dead space. J Clin Monit Comput 2012; 26(3):183-190.

22. Tusman G, Suarez-Sipmann F, Bohm SH, Borges JB, Hedenstierna G. Capnography reflects ventilation/perfusion distribution in a model of acute lung injury. Acta Anaesthesiol Scand 2011;55(5):597-606.

23. Proquitté H, Krause S, Rüdiger M, Wauer RR, Schmalisch G. Current limitations of volumetric capnography in surfactant-depleted small lungs. Pediatr Crit Care Med 2004;5(1):75-80.

24. Wenzel U, Wauer RR, Schmalisch G. Comparison of different methods for dead space measurements in ventilated newborns using $\mathrm{CO}_{2-}$ volume plot. Intensive Care Med 1999;25(7):705-713.

25. Nickles HT, Sumkauskaite M, Wang X, Wegner I, Puderbach M, Kuebler WM. Mechanical ventilation causes airway distension with proinflammatory sequelae in mice. Am J Physiol Lung Cell Mol Physiol 2014;307(1):L27-L37.
26. Mok Q, Negus S, McLaren CA, Rajka T, Elliott MJ, Roebuck DJ, McHugh K. Computed tomography versus bronchography in the diagnosis and management of tracheobronchomalacia in ventilator dependent infants. Arch Dis Child Fetal Neonatal Ed 2005;90(4): F290-F293.

27. Charron C, Repesse X, Bouferrache K, Bodson L, Castro S, Page $\mathrm{B}$, et al. $\mathrm{P}_{\mathrm{aCO}}$ and alveolar dead space are more relevant than $\mathrm{P}_{\mathrm{aO}_{2}} / \mathrm{F}_{\mathrm{IO}_{2}}$ ratio in monitoring the respiratory response to prone position in ARDS patients: a physiological study. Crit Care 2011; 15(4):R175.

28. Shakti D, McElhinney DB, Gauvreau K, Yarlagadda VV, Laussen $\mathrm{PC}$, Betit $\mathrm{P}$, et al. Pulmonary deadspace and postoperative outcomes in neonates undergoing stage 1 palliation operation for single ventricle heart disease. Pediatr Crit Care Med 2014;15(8):728-734.

29. Kallet RH, Jasmer RM, Pittet JF. Alveolar dead-space response to activated protein $\mathrm{C}$ in acute respiratory distress syndrome. Respir Care 2010;55(5):617-622.

30. Kolar M, Krizmaric M, Klemen P, Grmec S. Partial pressure of end-tidal carbon dioxide successful predicts cardiopulmonary resuscitation in the field: a prospective observational study. Crit Care 2008;12(5):R115

This article is approved for Continuing Respiratory Care Education credit. For information and to obtain your CRCE

(free to AARC members) visit

www.rcjournal.com 